\title{
The effect of processing on the vitamin A content of human milk
}

\author{
Karla D. S. Ribeiro, ${ }^{1}$ Illana L. P. Melo, ${ }^{1}$ Ana Z. O. Pristo, ${ }^{2}$ Roberto Dimenstein $^{3}$
}

\begin{abstract}
Objectives: To analyze the effect of processing on the vitamin A levels of milk that is donated to the Human Milk Bank at the University Maternity Hospital, and to evaluate whether this milk supplies the infants' vitamin A requirement.

Methods: Sixty milk samples from the Human Milk Bank were divided into two equal portions. One milk portion was extracted prior to processing, while another fraction was subjected to pasteurization and later extracted. The samples were analyzed using high performance liquid chromatography. Analysis with Student's t test indicated that the difference between mean retinol levels was statistically significant at the $\mathrm{p}<0.05$ level.

Results: The retinol content found in the milk prior to processing was $55.4 \pm 34.0 \mu \mathrm{g} / 100 \mathrm{ml}$, whereas for the processed milk this level was $36.6 \pm 26.1 \mu \mathrm{g} / 100 \mathrm{ml}(\mathrm{p}<0.001)$.

Conclusion: It was found that retinol loss occurs during milk processing and that the milk from the Human Milk Bank does not meet infants' vitamin A requirement.
\end{abstract}

J Pediatr (Rio J). 2005;81(1):61-4: Vitamin A, breast milk, human milk bank.

\section{Introduction}

Vitamin $A$ is a micronutrient that is essential for health and that is involved in physiological processes such as growth, fetal development and the integrity of the immune system. ${ }^{1}$ Human milk is the only source of vitamin A for infants exclusively fed from the breast and the capacity of children to acquire their requirements depends on the concentration and volume consumed. ${ }^{2}$

1. Nutrition student, Universidade Federal do Rio Grande do Norte (UFRN), Natal, RN, Brazil.

2. Nurse, coordinator of the Human Milk Bank, Maternidade Escola Januário Cicco, Natal, RN, Brazil.

3. Ph.D. Adjunct professor, Department of Biochemistry, Universidade Federal do Rio Grande do Norte (UFRN), Natal, RN, Brazil.

Manuscript received Aug 04 2004, accepted for publication Nov 172004.

Suggested citation: Ribeiro KD, Melo IL, Pristo AZ, Dimenstein R. The effect of processing on the vitamin A content of human milk. J Pediatr (Rio J). $2005 ; 81: 61-4$
Breastmilk from human milk banks (HMB) is an excellent nutritional alternative for preterm children, those with low birth weights, infectious diseases or diarrhea and the immunodepressed, ${ }^{3}$ when their mothers' milk is not available. The HMB collects, processes and stores milk from healthy women and also promotes maternal breastfeeding, making it an important part of governmental strategy for healthy nutrition. ${ }^{4}$ The milk collected is subjected to processing in the following stages: defrosting, re-bottling, pasteurization at $62.5^{\circ} \mathrm{C}$ for 30 minutes, cooling, sampling for microbiological quality control and storage in a freezer at $20{ }^{\circ} \mathrm{C}$ for up to 6 months. ${ }^{5}$

Processing may influence the nutritional composition of the milk, since there are nutrients that are sensitive to the action of temperature, oxygen and ultraviolet radiation. ${ }^{6}$ Dutra-de-Oliveira \& Marchini ${ }^{7}$ report that vitamin $A$ is relatively stable under the action of heat, but susceptible to oxygen and, primarily, to light due to the effects of ultraviolet rays. 
Research into the effect of processing on the nutrients in milk stored in HMB is extremely rare. Just one study describes concentrations considered inadequate $(<1.1 \mathrm{~mol} / \mathrm{l}) .{ }^{8}$ It is important to investigate whether the same occurs at other HMB and if so to what extent. Furthermore, it is imperative to verify the vitamin A nutritional coverage of the milk offered to infants, in particular those special cases who are exclusively fed with milk from the HMB, such as preterms. These children have a greater nutritional retinol requirement than at any other stage. ${ }^{9}$ This is the result of intense catabolism during the first weeks postpartum ${ }^{10}$ together with small stocks of retinol in the liver at birth, low concentrations of plasma retinol and low concentrations of retinol-carrying proteins in comparison with full term newborn babies. ${ }^{11}$ This study, therefore, aims to provide information which can be of use for HMB, who have the maximum interest in guaranteeing the nutritional quality of milk during pasteurization and freezing.

\section{Methodology}

The present study was approved by the Committee for Ethics in Research at the Universidade Federal do Rio Grande do Norte. Ten milliliters was collected from each of 60 milk samples, from different stages of lactation, from flasks of milk donated to the HMB at the Maternidade Escola Januário Cicco. Samples were divided into two $5 \mathrm{ml}$ portions. Both portions had been extracted according to Giuliano et al. ${ }^{12}$ but one had been previously subjected to pasteurization ( $62.5^{\circ} \mathrm{C}$ for 30 minutes) in accordance with the procedures employed at the HMB at the Maternidade Escola. The milk samples were defrosted in a microwave oven and after a pre-established period had elapsed (15 minutes) the flasks were immersed in an ice-filled plastic container for a further 15 minutes. Processing took place at the Biochemistry of Nutrition Laboratory at UFRN.

The hexane extract was evaporated into a nitrogen atmosphere in a Bain Marie at $37^{\circ} \mathrm{C}$. Residues were then suspended in $1.0 \mathrm{ml}$ of methanol (Merck) at High Performance Liquid Chromatography (HPLC) purity levels and agitated for one minute. The retinol content of the samples was determined by HPLC in a Shimadzu LC-10 AD Chromatograph, coupled to a Shimadzu UV-VIS detector SPD 10 AD and a Shimadzu Chromatopac C-R6A integrator with an LC Shimpack CLC-ODS (M) $4.6 \mathrm{~mm} \times 25 \mathrm{~cm}$ column. The chromatogram was developed under the following conditions: $100 \%$ methanol mobile phase at a flow rate of $1.0 \mathrm{ml} / \mathrm{min}$. Identification and quantification of retinol in the samples were established by comparison with retention times and areas of the relevant standards of all-trans retinol - SIGMA. Standard concentrations were confirmed by the specific extinction coefficient $(\varepsilon 1 \%, 1 \mathrm{~cm}=1,850)$ in absolute ethanol (Vetec) and a $325 \mathrm{~nm}$ wavelength. ${ }^{13}$

Figures for retinol were expressed as means and standard deviations and differences between numerical parametric data were tested with Student's $t$ test for paired samples. Differences were considered significant when $\mathrm{p}<0.05$.
Recommended daily retinol consumption for infants during the first 6 months of life was based on Dietary Reference Intake, ${ }^{14}$ which is equivalent to $400 \mu \mathrm{gROH}$, and for preterm children the recommendation proposed by Segre et al. ${ }^{9}$ which corresponds to $420 \mu \mathrm{gROH}$, was used. In order to calculate the retinol that would be consumed by an infant receiving milk from the $\mathrm{HMB}$, ingestion was assumed to be $500 \mathrm{ml}$ of milk per day, which volume corresponds to the first weeks of life. ${ }^{15}$

\section{Results}

The retinol concentration observed for milk prior to pasteurization was $55.4 \pm 34.0 \mu \mathrm{g} / 100 \mathrm{ml}$, whereas the level present in the processed milk was $36.6 \pm 26.1 \mu \mathrm{g} / 100 \mathrm{ml}$, equivalent to a reduction of $34 \%$. The difference between these means was statistically different $(p<0.001)$. When the nutritional adequacy of the milk was assessed, pasteurized and unpasteurized milk offered just $45.8 \%$ and $69.3 \%$ of the daily retinol recommendation for full term infants, respectively. For preterms, the processed milk offers just $43.6 \%$ of nutritional requirements for retinol (Table 1).

\section{Discussion}

The nutritional content of milk at an HMB depends on two factors: the composition of the milk donated and the effect of processing. Its composition is relatively constant, although certain nutrients vary significantly as lactation progresses, throughout the day and even during the course of a single feed. ${ }^{16}$ Vitamin $A$ is one example of such nutrients as it is influenced by the time of feeding/ expressing ${ }^{17}$ and by the stage of lactation. ${ }^{18}$

Defrosting, pasteurization and freezing are procedures that can affect several different nutrients contained in human. ${ }^{19}$ In the present study the retinol content of processed milk reduced with respect of the pre-pasteurization sample, as was found by Góes et al. ${ }^{8}$ Furthermore, the retinol level in the processed milk $(36.6 \pm 26.1 \mu \mathrm{g} / 100 \mathrm{ml})$ was also similar to the $31.46 \mu \mathrm{g} / 100 \mathrm{ml}$ found in the milk at the HMB at the Instituto Fernandes Figueira - RJ. ${ }^{8}$

The retinol lost during processing is probably the result of exposure to light during freezing and rebottling since vitamin $\mathrm{A}$ is photosensitive and the processing takes place in a very well-lit environment. Furthermore, the retinol present in milk could suffer from the influence of the microwaves used for defrosting. ${ }^{20}$ These results suggest that it is important to protect milk stored in glass flasks from light, including through preventative measures such as simply wrapping the flasks in aluminum foil. Another prophylactic measure could be vitamin A supplementation to guarantee infants their necessary supply, avoiding increased risks of morbidity and mortality.

Much of the interest in vitamin A in relation to preterms is due to its role in helping maintain the integrity of epithelial membranes, especially in the lungs, and to deficiencies being associated with an increased risk of developing chronic pulmonary disease. ${ }^{21,22}$ 
Table 1 - Mean retinol consumption by breastfed babies in the first weeks of life receiving human before and after processing by the HMB

\begin{tabular}{lcccc}
\hline Type of milk & ROH & Mean intake $*$ & \multicolumn{2}{c}{ \% of adequacy } \\
& $(\boldsymbol{\mu g} / \mathbf{1 0 0} \mathbf{~ m l )}$ & $(\boldsymbol{\mu g} / \mathbf{d a y})$ & Full term & Preterm \\
\hline Before pasteurizatin & $55.4 \pm 34.0$ & 277 & 69.3 & 66 \\
After pasteurization & $36.6 \pm 26.1$ & 183 & 45.8 & 43.6 \\
\hline
\end{tabular}

$\mathrm{ROH}=$ retinol. $\mathrm{HMB}=$ Human Milk Bank.

Requirements of the full term infant: $400 \mu \mathrm{g} / \mathrm{day}^{14}$; and preterm infant: $420 \mu \mathrm{g} / \mathrm{day}^{9}$.

* Considering a daily intake of $500 \mathrm{ml}$ of milk/day ${ }^{15}$.

According to the results of the present study, neither the retinol concentration of the milk before or after pasteurization is sufficient to meet the needs of children fed exclusively on milk from the HMB, in particular preterm babies whose needs for vitamin $A$ are greater and whose capacity for ingesting milk is lower than full term newborn babies. In order that these children can guarantee the formation of their hepatic reserves and protection against deficiency, retinol concentrations above $80 \mu \mathrm{g} / 100 \mathrm{ml}$ (Table 1) would be necessary.

The low retinol concentrations found in this study are probably the result of the predominance of mature milk in the samples analyzed. Such milk has lower concentrations of vitamin A when compared with colostrum, the secretions during the first week postpartum. One relevant aspect of the present research would be the suggestion that milk be classified by lactation stage when supplied for consumption since vitamin A levels decrease as lactation progresses. ${ }^{18}$ Taking into account the concentration of retinol found in the colostrum of low-income lactating women in the city of Natal - RN which was $93.10 \mu \mathrm{g} / 100 \mathrm{ml},{ }^{23}$ and based on the results of the present study, it would be interesting if the colostrum and transition milk were only given to newborn babies during their first week of life since milk obtained during the initial stages of lactation offers greater quantities of vitamin A than mature milk. Such a measure would guarantee milk with an adequate vitamin A supply in keeping with the infant's age.

The results of this study alert us to the need to reassess the procedures used at HMB which in turn could help maintain the nutritional quality of the milk offered to infants.

\section{Acknowledgements}

The authors would like to thank the Human Milk Bank of Maternidade Escola Januário Cicco, Universidade Federal do Rio Grande do Norte (UFRN), Natal, RN, Brazil.

\section{References}

1. Stoltzfus RJ, Underwood BA. Breast-milk vitamin A as an indicator of the vitamin A status of women and infants. Bull World Health Organ. 1995;73:703-11.

2. World Health Organization. Nutrient adequacy of exclusive breastfeeding for the term infant during the first six months of life. Geneva: WHO; 2002. p. 22-6.

3. Almeida JA, Novak FR, Almeida $\mathrm{CH}$, Chave RM, Araujo FM, Garrido JR. Recomendações técnicas para o funcionamento de bancos de leite humano. $2^{a}$ ed. Brasília, Brasil: Ministério da Saúde/Instituto Nacional de Alimentação e Nutrição/Programa Nacional de Incentivo ao Aleitamento Materno/Fundação Oswaldo Cruz/Instituto Fernandes Figueira; 1993.

4. Giugliani ER. Rede nacional de bancos de leite humano do Brasil: tecnologia para exportar. J. Pediatr (Rio J). 2002;78:183-4.

5. Ministério da Saúde. Normas gerais para bancos de leite humano. $2^{a}$ ed. Brasília: Ministério da Saúde; 1993.

6. Penteado MD. Vitaminas: aspectos nutricionais, bioquímicos, clínicos e analíticos. Barueri (SP): Manole; 2003.

7. Dutra-de-Oliveira JE, Machini JS. Ciências Nutricionais. São Paulo: Sarvier; 1998.

8. Góes HC, Torres AG, Donangelo CM, Trugo NM. Nutrient composition of banked human milk in Brazil and influence of processing on zinc distribution in milk fractions. Nutrition. 2002;18:590-4.

9. Segre CA, Armellini PA, Marino WT. RN. São Paulo: Sarvier; 1995.

10. Ruffier CP, Ruffier JG, Pagani JR, Barreto AP, Braz MG. Neonatologia. In: Waitzberg DL. Nutrição oral, enteral e parenteral na prática clínica. São Paulo: Atheneu; 2000. p. 1051-86.

11. Vinagre RD, Diniz EM. O leite humano e sua importância na nutrição do recém-nascido prematuro. São Paulo: Atheneu; 2002.

12. Giuliano AR, Neilson EM, Yap H, Baier M, Canfield LM. Quantification of and inter/intra-individual variability in major carotenoids of mature human milk. J Nutr Biochem. 1994;5: 551-6.

13. Nierenberg DW, Nann SL. A method for determining concentrations of retinol, tocopherol, and five carotenoids in human plasma and tissue samples. Am J Clin Nutr. 1992;56: 417-26.

14. Institute of Medicine. Dietary Reference Intake for vitamin A, vitamin K, Arsenic, boron, chromium, copper, iodine, iron, manganese, molybdenum, nickel, silicon, vanadium and zinc. 1st ed. Washington (DC): National Academy Press; 2001.

15. Ross JS, Harvey PW. Contribution of breastfeeding to vitamin A nutrition of infants: a simulation model. Bull World Health Organ. 2003;81:80-6. 
16. Neville MC, Morton J, Umemura S. Lactogenesis. The transition from pregnancy to lactation. Pediatr Clin North Am. 2001;48: 35-52.

17. Ribeiro KD, Dimenstein R. Níveis de retinol no leite materno ao início e final da mamada. Rev Pan Am Salud Publ. 2004;16:19-22.

18. Macias C, Schuweigert FJ. Changes in the concentration of carotenoids, vitamin A, alpha-tocopherol and total lipids in human milk throughout early lactation. Ann Nutr Metab. 2001;45:82-5.

19. Jensen RG. Miscellaneous factors affecting composition and volume of human and bovine milks. In: Jensen RG, editor. Handbook of milk composition. San Diego: Academic Press; 1995. p. 237.

20. Sieber R, Eberhard P, Fuchs D, Gallmann PU, Strahm W. Effect of microwave heating on vitamins $A, E, B 1, B 2$ and B6 in milk. J Dairy Res. 1996;63:169-72.

21. Glasziou PP, Mackerras DE. Vitaminas na gravidez e na primeira infância. Anais Nestlé. 1996;53:37-47.
22. Darlow BA, Graham PJ. Vitamin A supplementation for preventing morbidity and mortality in very low birthweight infants. Cochrane Database Syst Rev. 2002;2:CD000501.

23. Dimenstein $R$, Simplício JL, Ribeiro KD, Melo IL. Influência de variáveis socioeconômicas e de saúde materno-infantil sobre os níveis de retinol no colostro humano. J Pediatr (Rio J). 2003;79:513-8.

Corresponding author:

Roberto Dimenstein

Av. Praia de Genipabu, 2100/1402

CEP 59094-010 - Natal, RN

Brazil

Phone: +55 (84) 219.4340 